\title{
Sir George Newman, Infant Diarrhoeal Mortality and the Paradox of Urbanism
}

\author{
JOHN WALKER-SMITH*
}

\section{Introduction}

In Britain at the turn of the century, infant mortality was a cause of major concern to the government, the medical profession and the population at large. This sentiment was expressed with great clarity by George Newman (1870-1948) in his book Infant mortality: a social problem (1906), ${ }^{1}$ written when he was Medical Officer of Health for both an urban borough, Finsbury, ${ }^{2}$ and a rural county, Bedfordshire. Newman was later to become a civil servant of power and influence who played a key role in the shaping and implementation of government health policy. In 1907 he became Chief Medical Officer of the Board of Education, and in 1919 was also appointed Chief Medical Officer to the new Ministry of Health. Knighted in 1911, he retired in $1935^{3}$

In 1906 Newman was acutely aware that infant mortality was rising at the same time that the birth rate was falling. A great admirer of the advances being made in modern cities, yet he was confronted by the evidence of his own experience, as a Medical Officer of Health, that there was a much higher infant mortality in most but not all urban areas when compared with rural ones, and he was particularly disturbed by the high diarrhoeal mortality among infants. However, for him the situation was complex. In his book he explored the paradox of urban life as, on the one hand, the embodiment of civilization and, on the other, associated with an unacceptable death rate among infants. But his faith in the benefits of urbanism remained undimmed, and he believed that these far outweighed its debits, which could be remedied by social policy. He looked at the reasons why, in his opinion, urbanism was associated with a high infant mortality (especially diarrhoeal mortality) and made specific recommendations to rectify the situation, most of which were later implemented. Infant mortality, especially that associated with diarrhoea, fell dramatically in the first decades of the twentieth century. Newman believed that his recommendations had played an important part in this achievement, and many agreed with him. The extent to which this was true will be addressed in this paper.

\footnotetext{
*Professor J A Walker-Smith, University Department of Paediatric Gastroenterology, The Royal Free Hospital, Pond Street, Hampstead, London NW3 2QG.

The research for this article was undertaken during tenure of a fellowship with the Wellcome Institute for the History of Medicine provided by the Wellcome Trust. My deep thanks go to all the staff,
}

especially Dr Tilli Tansey who taught me so much, and Dr Christopher Lawrence and Professor Bill Bynum for their advice.

1 G Newman, Infant mortality: a social problem, London, Methuen, 1906.

2 Between 1901 and 1907 Newman published annual reports on the health of Finsbury.

3 Obituary, Br. med. J., 1948, i: 1112-13. 


\section{John Walker-Smith}

\section{Infant Mortality}

The two health districts in which Newman worked in 1906 differed significantly. Bedford was a prosperous rural county; Finsbury one of the poorest and most overcrowded of the London metropolitan boroughs. The figure for infant mortality in Bedford between 1901 and 1905 was 119 per 1,000 births, while that in Finsbury in 1901 was 140.6. In his 1901 report on the health of Finsbury, Newman wrote, "Infant mortality is one of the most reliable tests of the health of a community and of sanitary conditions of a district". ${ }^{4}$ Five years later, in the preface to Infant mortality he pointed out that the young contributed significantly to the bills of mortality because of their susceptibility to the influence of the environment. He held that "as civilisation advances, however, [infant mortality] should become less", but this was not happening in England and Wales in the early 1900s. Indeed, in 1906, 120,000 infant lives were lost. This failure to curb infant mortality at a time of declining birth rate was for Newman an important new factor. Although there had been occasions, for example in the eighteenth century, when infant mortality had been high, it had never been accompanied by a fall in the birth rate. Newman suggested that this high death rate must indicate "evil conditions in the homes of the people". Poverty per se was not the only factor responsible as he knew that in "many poor communities infant mortality was low". Likewise poor housing and the external environment could not by themselves account for high mortality. He concluded that "this loss of infant life is in some way intimately related to the social life of the people". 5 The evidence for these statements and the preventive strategies required formed the rest of his book.

\section{Infant Mortality as a Reflection of Physical Deterioration}

Newman wrote at a time of national and imperial concern about health issues in general and infant mortality in particular. There was great anxiety about what was perceived as the physical deterioration of the nation. The Boer War had drawn attention to the ill-health of recruits for the British army and this, together with the falling birth rate, were seen as bad omens for the British empire as a whole. For example, in "the Manchester district, where 11,000 men offered themselves for war service between the outbreak of hostilities in October 1899 and July 1900 ", no fewer than " 8,000 were found to be physically unfit to carry a rifle or to stand the fatigues of discipline". 6 The army itself was so concerned that it had sought advice from the Royal Colleges of Physicians and of Surgeons.

In New South Wales, a Royal Commission on Decline of Birth Rate and on Mortality of Infants had been appointed in 1903, and Newman quoted extensively from its report. ${ }^{7}$ In the same year in Britain, Parliament was promised an inquiry into the physical deterioration of certain classes of the population so that, in consultation with the medical profession, it could determine what the true facts were and find a means of arresting the

4 G Newman, Report on the health of Finsbury, 1901 , p. 18.

5 Newman, op. cit., note 1 above, pp. v, vi.

6 Arnold White, Efficiency and empire, London, Methuen, 1901, pp. 102-3, quoted in D Dwork, War is good for babies and other young children, London,
Tavistock Publications, 1987, p. 13.

${ }^{7}$ Report of the Royal Commission on Decline of Birth-Rate and on Mortality of infants in New South Wales, NSW Parliamentary Papers, vol. 4, 2nd session, 1904. 


\section{Sir George Newman and Infant Diarrhoeal Mortality}

physical decline of the nation. The British Medical Journal commented: "now, more than at any time in the history of the British people do we require stalwart sons to people colonies and to uphold the prestige of the nation."8 In 1904, the Report of the InterDepartmental Committee on Physical Deterioration was published..$^{9}$ Evidence had been taken from a wide range of people including medical practitioners, Newman among them, and the report discussed infant mortality, but the Committee found no evidence of inherited racial physical decline. This conclusion was of importance in the nature versus nurture debate and provided strong arguments against the view of the eugenicists who encouraged the reproduction of "positive" characteristics and discouraged the continuation of "negative" ones. ${ }^{10}$ Indeed, the Committee believed that education and environmental conditions were crucial for improving fitness, and that the problem of physical deterioration should be reversed by improving the health of the young.

It was these key issues of child health and nurture that Newman addressed in Infant mortality. The Committee itself had not conducted any original investigations but had only taken evidence and examined witnesses. What Newman did was to present evidence from his own experience in Finsbury and in Bedford. In addition, he reviewed in some detail the findings of others, particularly fellow Medical Officers of Health.

\section{Infant Mortality Rate in 1900s}

In 1905, 120,000 infants died in England and Wales. This figure constituted one-quarter of total deaths. In London in 1903 there were 70,281 deaths, with infants under one year accounting for 24 per cent. Infant mortality in England and Wales had not significantly improved since the mid-nineteenth century, and for London it was actually rising.

Newman regarded an infant mortality rate of 80 per 1,000 births as low and 250 per 1,000 as high. ${ }^{11}$ In England and Wales, with a population of 34,000,000 in 1905, the figure for the years 1891 to 1900 was 154 per 1,000, the same as it had been between 1851 and 1860 , but in 1905 there were 4 births fewer per 1,000 than in 1851 . The overall death rate had declined by 4 per 1,000, with the greatest reduction occurring between the ages of 5 and 25 years, on average a 50 per cent reduction, but the infant population had not shared this general improvement. One in six infants died before the age of 12 months.

The situation was similar in other countries, but there were clear signs of decreasing infant mortality in Australia, Ireland, Norway, Sweden, the Netherlands, Switzerland, Denmark, and above all in New Zealand with "a proud figure of 81 ". By contrast the figures were very high in Russia (272), Austria (227), and Chile (333). ${ }^{12}$

Newman was extremely impressed by the Australian and New Zealand statistics. He pointed out that to find better infant mortality rates than in northern Europe "we must take the wings of the morning to the new lands of the Australian Commonwealth and the island

8 Br. med. J., 1903, ii: 208.

9 Report of the Inter-Departmental Committee on Physical Deterioration, London, HMSO, 1904.

$10 \mathrm{~K}$ Pearson, The groundwork of eugenics, London, Eugenics Laboratory, 1909, p. 32.

11 Putting this into contemporary perspective, the infant mortality in England and Wales in 1992 was 6.6, the lowest ever recorded. The population of

\footnotetext{
England and Wales in 1974 was 49,195,100.

12 Newman, op. cit., note 1 above, pp. 6, 7. By comparison, present day infant mortality in developing nations in Africa and Asia is approximately 120 and 80 respectively. In many of these countries infantile diarrhoeal mortality is still high. Many of the issues raised by Newman apply in these countries.
} 


\section{John Walker-Smith}

of New Zealand". ${ }^{13}$ For Newman these were countries of great opportunities, but he was very concerned that the dangers of urban civilization were also beginning to affect them. In both New Zealand and Australia urban mortality rates were higher than those in rural areas. ${ }^{14}$ His perception that, even in the most fortunate situation, urbanism could adversely affect infant health explains Newman's interest in these countries.

The high infant mortality amongst illegitimate children in New South Wales, which appeared to be directly related to urbanism, especially attracted Newman's attention. In the years 1895-1902, the mortality of legitimate infants was 98.5 per 1,000, compared with 277.4 for illegitimates (23/4 times higher). He commented: "The high returns of illegitimate infant mortality in New South Wales are particularly striking when it is remembered that the environment of New South Wales is so favourable to infant life that it enjoys one of the lowest of all national infant mortality rates". An even greater worry was the decline in births, "however serious a high infant mortality may be to a State with a high birth rate, it assumes increased gravity if the state have a low birth rate, for in such event the candle is being burnt at both ends . . . No one can read the conclusions of the Royal Commission on the Decline of the Birth Rate in New South Wales, without realising the gravity of the situation". 15

In the early 1900s, the mortality rate in Australia as a whole aroused fears that an unfit metropolitan people, both at home in the British Isles and abroad in the dominions populated largely by people of British stock, would be unable to defend and develop imperial possessions in the growing rivalry between the British and German empires. This concern about population growth in Australia had both national and imperial dimensions and confronted Australians with their perennial situation of closely interwoven dual loyalties to the new land of their birth and to their ancestral homeland. ${ }^{16}$

In 1903, the convening of the New South Wales Royal Commission on Birth Rate and Infant Mortality and the London Committee on Physical Deterioration demonstrated that both Westminster and Sydney shared a concern about these matters. More important than the specific recommendations of the Royal Commission was the impact its report had upon public opinion in Australia, articulating the connections between infant health and both national power and imperial strength. In particular, it alerted the public to the dangers of urbanism.

\footnotetext{
13 Newman, op. cit., note 1 above, p. 18. The phrase comes from Psalm 139 , "If I take the wings of the morning and dwell in the uttermost parts of the sea", and reflects his Quaker views.

14 Although not quoted by Newman, contemporary figures for infant mortality from Queensland, as reported by Douglas Gordon in 1990 (Mad dogs and Englishmen went out in the Queensland sun, Brisbane, Amphion Press, 1990, p. 34) indicate the significant advantage of rural over urban environment in Australia at that time. In spite of the fact that the tropics were and still are regarded as unhealthy places, infant mortality rates for tropical Queensland between 1896 and 1905 were 99 per
}

\author{
1,000 deaths, and for Brisbane, 128 , and for the \\ period 1906-1915 had fallen to 90 and 64 \\ respectively. The latter figure is even lower than that \\ of New Zealand's 82 so admired by Newman. It is \\ possible, though not proved, that at that time \\ Queensland may have had the lowest infant mortality \\ rate in the British empire apart from the Scottish \\ rural counties of Argyll and Zetland (60.2 and 61.2). \\ 15 Newman, op. cit., note 1 above, pp. 215, 213. \\ 16 M Lewis, "The "health of the race" and infant \\ health in New South Wales: perspectives on \\ medicine and empire', in R Macleod and M Lewis \\ (eds), Disease, medicine and empire, London, \\ Routledge, 1988, pp. 301-15.
}




\section{Sir George Newman and Infant Diarrhoeal Mortality}

\section{Geography of Infant Mortality in Great Britain}

Newman investigated in some detail the geographic distribution of infant mortality in Britain. The worst figures came from the mining and manufacturing towns of the Midlands and the north of England. Scotland overall had a much lower infant death rate, for example, Argyll 60.1, Zetland 61.2, Caithness 73.3, Bute 74.9 and Forfar 78.5. As Newman saw it, the evil effects of population density, an inevitable characteristic of towns, usually caused infant mortality rates to exceed those in rural areas, especially in the later months of the year. However, exceptions could occur, for example, Ampthill rural district in the county of Bedford had 3 acres of land per person and an infant mortality of 91 per 1,000, but the town of Ampthill with one acre per person, had a mortality of 79 . Thus density of population per se was not the sole cause of infant mortality. As Arthur Newsholme had pointed out in 1891, "in good-class model dwellings, though the density of persons per acre was high, the infant mortality rate was low". ${ }^{17}$

Newman compared five mining and manufacturing counties, three manufacturing towns: Preston, Leicester and Blackburn, and three rural counties, Hertfordshire, Wiltshire and Dorset. The social conditions in the three towns in 1889, 1890 and 1891 "destroyed infants" throughout the first year of life especially in the later months of the year. This contrasted greatly with the three agricultural counties, where the rates were very much lower. He then looked at metropolitan London where between 1901 and 1905 the average infant mortality rate was 138 . However, this varied widely according to the borough, as the following figures indicate: City of London 138, Hackney 129, Finsbury 139, Bethnal Green 151, Shoreditch 179, Holborn 109 and Hampstead 97. As might be suspected, the highest figures were those of the most deprived boroughs and the lowest of the most affluent. Newman thus observed that the higher the death rate the more "urban" the community. However, he recognized it was a complex matter and that, as well as high population density, a wide variety of social, industrial and other conditions, including domestic insanitation, played a part.

\section{The Causes of Infant Mortality}

Newman then reviewed the three chief causes of infant deaths in England and Wales: first, premature birth, congenital defects, atrophy and immaturity (in the first weeks of life); second, respiratory (peak in the second month) and diarrhoeal illnesses (with a zenith at 3-4 months); third, whooping cough and measles (worse in the second month). All diseases of infancy were more common in towns than in the countryside; with immaturity twice as fatal in urban areas. In order of priority, he listed the causes of urban fatality among infants as immaturity, diarrhoea, nervous diseases and convulsions, and respiratory; and in the countryside as immaturity, respiratory, nervous diseases and convulsions.

He concluded from this initial review that infant mortality increased in the wake of urbanization, and that rural life was favourable to infancy. He singled out epidemic diarrhoea as the second most important cause of infant deaths in urban counties, where it was nearly 50 per cent higher than in rural ones; but by the end of the nineteenth century, there was evidence of a rise in infant diarrhoeal mortality in these rural areas too.

17 Newman, op. cit., note 1 above, p. 34. See also John M Eyler, Sir Arthur Newsholme and state medicine, 1885-1935, Cambridge University Press, 1997. 


\section{John Walker-Smith}

\section{Epidemic Diarrhoea}

Newman regarded epidemic diarrhoea as essentially preventable. He precisely defined the condition (zymotic or epidemic enteritis) as an acute infective disease affecting chiefly children under two years of age, occurring during summer months in epidemic form and characterized as a rule by the occurrence of diarrhoea, vomiting and convulsive phenomena, and wasting, accompanied in severe cases by toxaemia and collapse. It was often fatal, and, despite improvements in sanitation, was on the increase, but there was a clear difference between urban and rural counties. Newman reviewed the evidence for this deteriorating situation. He compared the annual death rates for infancy per million persons living in England and Wales with those for the 1850s. There appeared to have been an increase in mortality from diarrhoea in 1890s although an accurate comparison could not be made before 1875 as cholera had then been included in the figures. In London, epidemic diarrhoea as a percentage of deaths, rose from 10.7 between 1854 and 1859 to 15.1 between 1899 and 1903, a percentage increase of 41.1. Newman also reported that in New South Wales, although there was a general decline in infant deaths, there had been an increase in the number of fatalities due to diarrhoea, particularly in the second trimester of the first year.

In reviewing bacteriological knowledge of diarrhoea current in 1906, Newman referred to the classic researches of the Austrian paediatrician Theodor Escherich, who had observed the presence of B. coli communis (in modern terminology Escherichia coli) in normal stools. ${ }^{18}$ Newman acknowledged the failure by subsequent observers to identify with any consistency specific bacterial pathogens in the stools of children with epidemic diarrhoea. But he quoted from the work of Sheridan Delépine, Professor of Pathology in Manchester who theorized that

Epidemic diarrhoea of the common type occurring in this country is apparently, in the great majority of instances, the result of infection of food by bacilli belonging to the colon group of bacilli, and which are present at times in faecal matter. It appears that this infection of food does not generally lead to serious consequences, unless the infection is massive from the first, or the food is kept for a sufficient length of time, and under conditions of temperature favouring the multiplication of these bacilli.

Newman then observed: "our knowledge of the conditions which favour the occurrence of this disease are, on the whole, further advanced than our knowledge of its etiology". ${ }^{19} \mathrm{He}$ paid especial tribute to the contribution of Dr Edward Ballard in this regard. Medical Officer of Health in Islington from 1856 to 1870 and then Inspector to the Local Government Board from 1871 to 1890 , Ballard had published in 1889 his 'Report of the Medical Officer for 1887 on diarrhoea' as a supplement to the 17th annual report of the Local Government Board 1887-88. ${ }^{20}$ In this he recognized three agents as playing a part in the causation of epidemic diarrhoea, namely soil, season and food. The causa causans was "some micro-organism not yet detected or isolated". Ballard further recommended nine sanitary remedies to prevent epidemic diarrhoea. These were: removal of liquid and

18 Ibid., p. 145.

19 Sheridan Delépine, writing in J. Hygiene, 1903, 3 (1): 89-90, quoted in Newman, op. cit., note 1, above, p. 148 , see also p. 149.
20 E Ballard, Supplement to 17th annual report of the Local Government Board 1887-1888, London, HMSO, 1889. 


\section{Sir George Newman and Infant Diarrhoeal Mortality}

solid filth by proper drains and sewers; domestic and social hygiene; sealing of the soil around dwelling houses; lowering ground water to prevent dampness; prevention of soil emanations; free ventilation about and within dwellings; protection of food from infection and contamination; improved regulations for sewers and drains; and measures of advance in general sanitation. ${ }^{21}$

All except two of these recommendations had been carried out in large measure, yet epidemic diarrhoea was still increasing with the consequent mortality. The exceptions were, in Newman's view, domestic and social hygiene, and the protection of food from infection and contamination. Newman's thesis was that improvements in general sanitation and ventilation had proved inadequate to reduce infant mortality, especially from infantile diarrhoea. Further reduction could be achieved only by maternal education. This was especially important for the urban English mother living in an industrial environment, although less so for those who still breast-fed their babies as part of their natural culture, such as the Italian mothers of Finsbury or the Irish mothers of Dublin and Connaught. In the eyes of Newman's critics, however, a low infant mortality in such poor communities provided a strong case against educating mothers. William Brend scornfully wrote, "We cannot assume that the Connaught peasantry, many of whom can neither read nor write, are so much better instructed in the care of infants, that in spite of poverty and hard conditions, infant mortality among them is half that among the mothers of Kensington". 22 But this argument ignored Newman's belief that urbanization in Edwardian times was de-skilling mothers, who had now lost the capacity to feed their infants naturally. They were victims of industrialization. Only education could free them. Newman also observed:

It is evident that our knowledge of the bacteriology of diarrhoea is not sufficiently established to permit of any very definite conclusion on the matter. It may be that the whole group of choleraic, enteric and diarrhoeal diseases are caused by a group of micro-organisms having many similarities and relationships to each other; or it may be that different forms of diarrhoea have their own casual organism; or lastly, it may be a question of association of organisms or of toxins which brings about the disease. In any event there is abundant evidence that epidemic diarrhoea is a specific disease caused by bacteria. ${ }^{23}$

This last sentence reveals the conceptual framework within which he worked and which was to be the basis of his preventive strategy, i.e., epidemic diarrhoea is an infective disease even in the absence of bacteriological proof. This idea, which significantly influenced his contemporaries-in particular his fellow Medical Officers of Health and paediatric clinicians - provided a theoretical basis for the malady to be regarded as a "filth disease". In his 1901 Report on the health of Finsbury, he had stated "Epidemic diarrhoea is a so-called filth disease and preventable by improved sanitation and public hygiene in the broad meaning of the terms". ${ }^{24}$ As evidence, he referred to epidemiological data which substantiated the infective nature of epidemic diarrhoea. He detailed his own experience in Finsbury, as well as that of a wide range of investigators, especially fellow Medical

21 Newman, op. cit., note 1 above, pp. 144-50.

22 William Brend, 'The relative importance of prenatal and post-natal conditions as causes of infant mortality', in National Health Insurance Medical Research Committee, The mortalities of birth, infancy and childhood, London, HMSO, 1918, p. 11.

23 Newman, op. cit., note 1 above, p. 149.

$24 \mathrm{G}$ Newman, Report on the health of Finsbury, 1901, p. 80. 
Officers of Health, such as Dr Edward Ballard of Islington, Dr Arthur Newsholme of Brighton, Dr Niven of Manchester, and Dr Hope of Liverpool.

Newman then considered in more detail the conditions most favourable to epidemic diarrhoea, which in infants was often called summer diarrhoea because of the high peak of cases at that time of year. He began by examining the possible effects of high summer temperature. In his 1887 report, Ballard had set out the results of his investigations into the role of environmental temperature in the summer months. He had compared atmospheric temperature and temperature recorded in the soil at depths of one foot and four feet; he found that the summer rise in infant diarrhoeal mortality did not commence until the mean temperature recorded by the four-foot earth thermometer had gone above $56^{\circ} \mathrm{F}$, no matter what had been recorded by the one-foot or the atmospheric thermometers. The decline of diarrhoeal mortality coincided with the temperature decline as recorded at four feet. Newman studied the four-foot temperature in Finsbury using a thermometer placed in Wilmington Gardens. In general, he confirmed Ballard's findings, but found discrepancies in some years.

For Ballard, the temperature of the soil four feet down was of great importance with regard to epidemics of infantile diarrhoea. There was, he suggested, an increase in "miasm" in the soil. (This must be one of the last occasions in modern times when a disease was attributed to miasma theory, as the germ theory had become widely accepted by the end of the nineteenth century.) Newman carefully refuted Ballard's theory, stating that "there is abundant evidence that epidemic diarrhoea is a specific disease caused by bacteria", 25 thus accepting the contemporary scientific view of its aetiology as a bacterial disease. Its occurrence depended wholly or partially upon surrounding temperature, level of rainfall and pollution of food, chiefly milk. All these factors were most relevant in urban areas, for 75 per cent of deaths in England and Wales from this disease occurred under one year of age, and of these 75 per cent were in London and other big towns.

His conclusions were that diarrhoeal diseases were very much more fatal in urban districts than rural; more dangerous to boys than to girls; a cause of havoc in the first year of life (accounting for one-fifth of mortality); and that they were aggravated by bad housing, poverty, artificial feeding, and domestic insanitation. In poor houses diarrhoea alone might cause an infant mortality of 30 or 40 per 1,000 births, three or four times that in better houses. What most concerned Newman was the worsening situation. "Taking together diarrhoeal diseases and diseases of the stomach and the liver, the recent five years show an increase of more than $70 \%$ in urban and nearly $70 \%$ in rural counties". ${ }^{26}$ So although rural counties had a lower mortality this was also rising. He was convinced that this deteriorating situation was related to social issues such as overcrowding but it was difficult to measure exactly the effect these had on death and sickness rates, although it was clear that overall they were detrimental. In Finsbury he attempted to relate social ills directly to mortality by, for example, comparing the size of the tenement with the death rate-the smaller the tenement, the more overcrowded. He demonstrated that the overall death rate from all causes of the zymotic diseases (smallpox, scarlet fever, diphtheria; fever, diarrhoea, measles and whooping cough) was significantly higher in one-room tenements.

25 Newman, op. cit., note 1 above, p. 149.

26 G Newman, Report on the health of Finsbury, 1905, p. 150. 


\section{Sir George Newman and Infant Diarrhoeal Mortality}

Finsbury was particularly badly affected by the growth of warehouse and workshop accommodation, and by the invasion of "self-contained" houses by the industrial population. Whole streets and squares of houses, formerly occupied by single and "often good-class families", were now divided up into separate dwellings on separate floors. The private house had become a tenement. The sanitary conveniences, water supply and washhouse designed for one family now had to provide for four. "The yards in the rear of the houses have, in many cases, been built over. These may be used for industrial purposes. Ventilation is poor and the houses effectively become back to back . . . It is impossible to rear a healthy physical race under such conditions as these". ${ }^{27}$ Slums yielded high death rates. Newman cited the Aylesbury Place area in Finsbury, where between 1895 and 1899 the annual infant mortality rate was 447 per 1,000 births, compared with 168 for the whole parish in which it was situated. "Previous to demolition, this insanitary area grew steadily worse and the infant death rate rose even higher than this enormous figure".28

As further evidence, Newman referred to the work of Dr John Robertson, Medical Officer of Health for Birmingham, who had studied the number of infant deaths from diarrhoea and enteritis in a cross-section of Birmingham districts from the very poor to the well-off, and concluded that diarrhoeal infant mortality rates were much higher in poverty-stricken neighbourhoods with bad social conditions. ${ }^{29}$

Having established that infant diarrhoeal mortality was related to social factors, Newman then looked at why it was increasing in urban areas. The report of the InterDepartmental Committee on Physical Deterioration had stated that "the increased mortality from diarrhoeal diseases is probably attributable in great part to the prevalence of artificial feeding and this appears to be consistent with the fact that the increase has been greater in the urban than in the rural counties". ${ }^{30}$ Newman, in his textbook on bacteriology, had described the role of infected milk in public health. He now argued that infantile diarrhoea was mainly due to domestic infection of milk or other articles, of which there was most risk in urban environments. ${ }^{31}$ Yet contaminated cow's milk on its own could not, as some observers maintained, be regarded as the sole explanation for infantile diarrhoea. This was too simplistic. Newman believed that "infant mortality is a social problem concerning maternity". ${ }^{32}$ The ignorance and carelessness of mothers caused a large proportion of infant deaths in England and Wales. This revealed itself in many ways, but chiefly in infants being given contaminated food as well as in general uncleanliness. It could operate amid every sort of external environment, good, bad and indifferent, and was not necessarily due to poverty per se. Evidence for this was based on epidemiological observations that in the "worst districts" there were many instances in which parents had successfully reared every member of a large family without any deaths. Side by side with these were numerous examples of families where death in infancy was common. The difference between these families had nothing to do with the season and was not wholly due to the parents' physical condition or the sanitary condition of their home, or even

27 Ibid., p. 185.

28 Ibid., p. 31.

29 Newman, op. cit., note 1 above, p. 191.

30 Newman, op. cit., note 26 above, p. 39.

31 G Newman, Bacteria, especially as they are related to the economy of nature, to industrial processes, and to the public health, London, John Murray, 1899.

32 Newman, op. cit., note 26 above, p. 328. 


\section{John Walker-Smith}

poverty. It lay in the amount of knowledge and intelligence, attention and care which the mother was able to bestow upon her offspring, applied throughout the year and, not infrequently, it operated in one family for a long time.

With this in mind, Newman commented, "we are faced with one all-pervading primary need-the need of a high standard of physical motherhood". ${ }^{33}$ Whilst improved sanitation, better housing, cheap and good food, domestic education and a healthy life of body and mind were all conditions leading to efficient motherhood, it was, nevertheless, clear that the baby depended not only on the health but also on the intelligence, the devotion and the maternal instinct of the mother.

Following his careful analysis of causes of infant mortality, Newman made a number of very specific recommendations. First, he advocated reorganization of existing agencies to improve the situation for mothers by ensuring that the regulations covering maternity leave and preventing the early return to work of mothers should be enforced. This was important because he had established that the occurrence of infant mortality in industrial districts was clearly related to the occupation of women in factories and workshops up to the time of confinement. Their return to work too early deprived the infant of necessary nursing and feeding after birth. It was also important to ensure that mothers were fed properly. He suggested adopting the successful French experience with Coullett restaurants for mothers, where food was provided gratis.

Second, as death in infancy was due more to ignorance than to any other cause, three measures needed to be carried out: (a) instruction of the mother in how to care for her children; (b) appointment of a lady health visitor who should become the friend of the household and should not be an inspector although qualifications were important; and (c) education of girls in domestic hygiene. In addition to these, he urged certain practical measures: birth registration ${ }^{34}$ (with a financial incentive for early registration); child protection; and promotion of breast feeding, and, when this was not possible, provision of clean milk.

The "great requirement" was breast feeding of infants. Realistically and without the zealot's passion, he acknowledged that this was not always possible, as a mother might be unable, for one reason or another (including being a bread-winner), to furnish a natural supply of milk for her child, so a considerable number of mothers were unable to feed their children. He therefore recommended that milk depots be set up to supply pure milk, suitably modified, to make it as much like human milk as possible.

\section{Newman's Conclusions}

Newman's conclusions and recommendations were based largely on epidemiological research. His personal preventive strategy centred upon maternal health education with two specific goals: to encourage breast feeding, and to achieve high standards of personal hygiene. Newman believed the human infant required the basic primitive needs of food and warmth and cleanliness.

33 Newman, op. cit., note 1 above, p. 257.

34 Historically, registration had begun in England in 1812 but this was only registration of baptisms. In 1836 registration of births, deaths and marriages was required but no time limit was set. In 1874 birth registration was required within 42 days of birth in England and Wales, although in Scotland in 1854, registration was required within 21 days. 


\section{Sir George Newman and Infant Diarrhoeal Mortality}

The dramatic fall in infant diarrhoeal mortality specifically, and the fall in infant mortality generally, which occurred in the next two decades, was one of the great success stories of the early twentieth century. Topley and Wilson in the third edition of their textbook in 1946 showed that infant diarrhoeal mortality fell from 23 in 1901-5 to 18 in $1906-10,19$ in 1911-15, 9 in 1916-20, down to 5 in 1931-35. ${ }^{35}$ The decline in infantile diarrhoea probably had a greater impact on the total figures than could be accounted for by the improvement of infant diarrhoeal mortality per se. This is because many of the cases of "atrophy" and failure to thrive (a prominent listed cause of mortality at that time) were in reality food intolerance syndromes occurring as a sequel to infective diarrhoea, i.e., post-enteritis syndromes. Although the measures that brought about this improvement to infants' health were based on the idea that infantile diarrhoea was infectious, all Newman's proposals for prevention were made without absolute laboratory proof of any bacterial causation.

Newman marshalled his own and other evidence to great effect, but he was not an innovator and several of his contemporaries had similar views on maternal education and breast feeding. It is, therefore, difficult to determine Newman's specific influence on the fall of infant diarrhoeal mortality. None the less, his work was quoted extensively in some major paediatric texts. In 1913 Sir Archibald Garrod in the widely read Diseases of children, recommended Newman's Infant mortality for providing "much information in regard to the aetiology" of infant mortality. ${ }^{36}$ Ralph Vincent, paediatrician to the Infant's Hospital, Westminster, in his 1910 book on The nutrition of the infant quoted extensively from Newman's book in his chapter on 'Zymotic enteritis' ${ }^{37}$ In the lay press, the Morning Post of 1911 reported that Infant mortality helped to draw attention to this subject and materially aided the initiation of a public movement on behalf of prevention. ${ }^{38}$ Yet Newman also had his critics, such as Dr William Brend of the Medical Insurance Research Council who believed that he had under-estimated the significance of poverty, inadequate housing and sanitation. ${ }^{39}$

Nevertheless, in 1939 Newman was able to conclude that from "1901 to 1910 the infant mortality rate was reduced to 128 per thousand, but from 1910 it fell in twenty years to 60 per thousand ... The agency of reform has not been due to improved sanitation so much as more enlightened motherhood ... Through the simple, practical and as it proved, farreaching instruction of health visitors and schools for mothers, several million mothers became child conscious". ${ }^{40} \mathrm{He}$ believed that an almost universal maternal awakening was responsible for this change in the outlook for child health and that this directly contributed to a fall in diarrhoeal mortality, thereby vindicating his views.

\section{Independent Assessment of Newman's Contribution}

Support for the view that a fall in diarrhoeal mortality was a major factor in the fall in infant mortality comes from Milton Lewis. When describing the notable fall in infant mortality that also occurred in New South Wales at the beginning of the century, he

\footnotetext{
35 Topley and Wilson's principles of bacteriology and immunology, 3rd ed. revised by G S Wilson and A A Miles, London, Edward Arnold, 1946.

36 A E Garrod, F E Batten and $H$ Thursfield, Diseases of children, London, Edward Arnold, 1913, p. 166.
}

\footnotetext{
$37 \mathrm{R}$ Vincent, The nutrition of the infant, 3rd ed., London, Baillière, Tindall and Cox, 1910.

38 Morning Post, 6 Aug. 1911.

39 Brend, op. cit., note 22 above.

$40 \mathrm{G}$ Newman, The building of a nation's health, London, Macmillan, 1939, p. 312.
} 


\section{John Walker-Smith}

attributes this to a decline in deaths from infectious diseases, "the most notorious of which was diarrhoeal disease". This improvement in infant health was not merely coincidental with the rise of infant welfare, which actively promoted breast feeding, but a direct result of it. ${ }^{41}$ Newman's contribution to this change was acknowledged by J Smith in 1955 , when he praised Infant mortality as an "outstanding work". 42

There is no doubt that Newman was a major player in the development of the concept of child health and infant welfare in Britain and much of the British empire. This was recognized in Australia where Newman was made an honorary member of the Public Health Association of Australia. He was also invited to the inaugural meeting of the Royal Australasian College of Physicians in 1938, but was unable to attend. However, he visited Canada twice, where he was made honorary LLD of the universities of McGill and Toronto.

As already noted, Newman had his contemporary critics, among them William Brend, who challenged his emphasis on enlightened motherhood, and criticized him for underestimating the significance of environmental factors. But a careful reading of Infant mortality makes it hard to sustain such criticism. In a lecture on 'Poverty and disease' in 1910 in Oxford at a meeting over which Sir William Osler presided, Newman made it clear that he recognized keenly the effect of poverty on child health. ${ }^{43} \mathrm{He}$ advocated slum clearance in Finsbury, and in Infant mortality, he endorsed all Ballard's proposals for improved sanitation, which by 1906 had largely been implemented, but his thesis was that these practical steps had proved inadequate without maternal education.

Is there another explanation for the great decline in infant diarrhoeal mortality, apart from increased maternal awareness and the associated promotion of breast feeding referred to above? Thomas McKeown has maintained that there is: the decline of gastroenteritis presented a problem (a central one in the interpretation of infant mortality) which arose from uncertainty about the infective nature of the disease. It is now clear that the provision of a safe milk supply was the main reason for the reduction of deaths from gastro-enteritis and contributed substantially to the fall of infant mortality from $1900 .^{44}$

Provision of clean milk per se is too simple as a complete explanation for the fall in infant diarrhoeal mortality. This view ignores the successful role of breast feeding. Furthermore, evidence exists suggesting that dirty milk was still a problem as late as the 1930s, long after the dramatic fall in diarrhoeal mortality had occurred. ${ }^{45}$ The fall in infant mortality and infant diarrhoeal mortality in the twentieth century must have had many causes, and it is generally agreed that these were chiefly social rather than specifically medical.

\section{Alternative Strategies}

Could Newman have suggested a solution to the problem of infant diarrhoeal mortality other than the recommendations he made in his book? He could, for example, have completely abandoned urbanism and suggested a general return to the country for mothers

\footnotetext{
41 Milton Lewis, 'Some infant health problems in Sydney, 1880-1939', J. R. Australian hist. Soc., 1982, 68: 70 .

$42 \mathrm{~J}$ Smith, The aetiology of epidemic infantile gastroenteritis, Royal College of Physicians of Edinburgh, 1955, p. 10.
} 


\section{Sir George Newman and Infant Diarrhoeal Mortality}

and babies with a widescale re-direction of the population and a massive programme of slum clearance. Another alternative could have been to recommend, like Dr Barnardo, large-scale emigration to the dominions such as Australia and New Zealand, countries he so admired.

There was no doubt that Newman shared the opinion of many in Edwardian society that the modern world created such urban misery that, by contrast, the countryside was idyllic. However, he suggested no radical answer to this concern; his approach was reform, not revolution. So here was a paradox. He shared the wish of many social thinkers in England to contain industrial values and to reassert humanism (in his own meaning), yet he did not advocate a return to the rural idyll. Instead he welcomed the benefits of urbanism. For him, applied science held the key to a new and exciting future which had the potential for all to fulfil their inheritance from nature. Thus by favourable nurture, an individual would be able to achieve his germ plasm (genetic) potential.

But at the same time he disapproved of certain forms of urbanism. The industrial revolution had proved that free competition can produce wealth without corresponding well-being - the life in the new mills had caused a terrible deterioration of physique and national health. This attitude ties in with Lewis's statement that at the turn of the century, the urban environment was feared to be producing a race of degenerates who were physically stunted and morally inferior. ${ }^{46}$

For Newman, the worst feature of the nineteenth century had been the driving of women and children into the factories; but with municipal reform there was hope for a better future. Indeed, he then conceived the positive idea of the town as a sanitary and health centre of domestic and industrial life, a focus of civilization, which reversed the evils of urban living. By criticizing urbanization, Newman was echoing the concerns that had been expressed by many Victorian and Edwardian social thinkers about the advancing world of industrial capitalism. Charles Dickens, for example, despite his early enthusiasm for progress, became repelled by the new society of commerce and production. His fictional world, according to Martin Wiener, led from the old England of John Bull and stage coaches through the feverish new urban and industrial society, to end in a cathedral town among public school men (The mystery of Edwin Drood) ${ }^{47}$

Nevertheless, Newman was not a revolutionary, rather an idealist who believed he could play a major role by reforming the urban environment. In his annual reports of the public health of Finsbury, he always sounded a note of progress and indeed of optimism. He recognized urbanism as both a direct contributor to the development of civilization (and indeed of imperialism), and a cause of many infant deaths. But he believed that this major drawback could be removed by the promotion of maternal education within the urban environment. Thus he was able, by this relatively simple strategy, to reconcile his admiration for the development of the modern city with its deplorable adverse social consequences for many women and their babies. Although he realized the importance of the general sanitary reforms of the nineteenth century, these were not enough. He saw the

\footnotetext{
46 Jane Lewis, 'Providers, "consumers", the state and the delivery of health-care services in twentiethcentury Britain', in A Wear (ed.), Medicine in society, Cambridge University Press, 1992, pp. $317-47$.
}

\footnotetext{
$47 \mathrm{M}$ Wiener, English culture and decline of the industrial spirit 1850-1980, London, Pelican, 1985, pp. 14.
} 


\section{John Walker-Smith}

health education of the population as a whole, mothers especially, as the major and essential innovation for the new twentieth century.

\section{Conclusion}

The impact of child care practices upon child mortality overall and infant mortality in particular, at the beginning of the twentieth century, is an issue that has interested writers in a variety of fields for some time. In 1925 in the United States, Robert Woodbury used statistical analysis to demonstrate the benefits of breast feeding upon infant mortality in the period 1916-18. ${ }^{48}$ More recently, Samuel Preston has built on this using statistical analysis based upon the American census of $1910 .{ }^{49} \mathrm{He}$ found that foreign-born Jews had a 43 per cent lower mortality than whites of parents born in the United States, while foreign-born French-Canadian children had a 40 per cent higher mortality. Foreign-born Jews were breast-fed for the longest period, French-Canadian children for the shortest.

Although Newman did not use statistics, he observed a similar situation in the Italian quarter of Finsbury. ${ }^{50}$ This important piece of evidence led him to adopt his view of the beneficial effects of breast-feeding, a conviction not unique to Newman and held by other observers in the United States and France, as well as in Britain and the Empire. But the gathering together of much information to back up his case in Infant mortality played a major part in disseminating the view and the preventive measures he advocated. If it be allowed that the education of mothers which subsequently occurred was indeed a major factor in the dramatic decline in infant mortality in the second and third decades of the twentieth century, this success is quite remarkable. There was a dramatic fall not only in infant diarrhoeal mortality but also in other related disorders, for example, what Newman called "atrophy", which would now be described as marasmus. Thus, although this fall in infant diarrhoeal mortality was initially the most dramatic amongst the various causes of infant mortality, the overall infant mortality fell at a greater rate than can be accounted for by this factor alone. For historians the translation of old medical diagnoses into contemporary nosological categories poses a great problem. ${ }^{51}$ However, modern paediatricians familiar with post-gastroenteritis syndromes of chronic diarrhoea and failure to thrive (still so common in the developing world) are not surprised by the coincident decline in marasmus as an important factor in infant mortality.

Infant mortality preaches an environmental view-point underpinning Newman's professional ideology of preventative medicine similar to that of his fellow Medical Officers of Health in Britain. As Dorothy Porter has observed, in Edwardian times these men promoted regeneration of the urban environment through nurture rather than nature. ${ }^{52}$ In her view, eugenics played very little part in British public health policy. The whole of Infant mortality is consistent with this. Newman advocated a holistic approach to the solution of the social problem of a rising infant mortality. He endorsed the need for better sanitation, slum clearance, etc., but he regarded these measures as of less importance than maternal education.

48 R M Woodbury, Causal factors in infant mortality: a statistical study based on investigations in eight cities, Washington, DC, US Government Printing Office, 1925.

49 Samuel H Preston, 'After Fatal years: responses and future research', Bull. Hist. Med., 1994, 68: 124-8.

\footnotetext{
50 Newman, op. cit., note 1 above, p. 225.

51 Preston, op. cit., note 49 above.

52 Dorothy Porter, 'John Ryle: doctor of revolution', in Dorothy Porter and Roy Porter (eds), Doctors, politics and society: historical essays, Amsterdam and Atlanta, Rodopi, 1993, pp. 247-74.
} 


\section{Sir George Newman and Infant Diarrhoeal Mortality}

It is clear that Newman was by no means unique in his concern about infant diarrhoeal mortality. In the United States and France there were many voices advocating the preventive value of breast feeding. Some, especially in France, have been accused of giving breast feeding a political role. The bourgeoisie were even accused of decadence and contributing to the depopulation of France by their failure to breast feed. Alisa Klaus has further stated that physicians attached a significance to breast feeding which transcended its physiological importance. ${ }^{53}$ Newman's approach was far more factual and non-emotive.

Jane Lewis has argued that Newman's views on health education were a matter of vital importance for public health. ${ }^{54}$ Dyhouse, sees the word "social" in the sub-title of Infant mortality as crucial in leading to a recognition of the importance of environmental conditions played in infant mortality. ${ }^{55}$ Similarly, Marland has recognized that the book was "influential in relation to the Huddersfield scheme" which achieved major improvements in infant welfare. It led directly to an abandonment of "emphasis on milk provision in favour of education and visiting". 56 The importance of Newman's work on the bacteriology of milk has been acknowledged also by T B Mepham. ${ }^{57}$ Deborah Dwork is the only medical historian to discuss in any detail Newman's views on epidemic diarrhoea, recognizing that this illness occupied a prime position in his public health policy in general, not only because of its importance as a cause of infant mortality, but above all because it was a disease preventable by maternal education. 58

With the establishment of the Ministry of Health by Act of Parliament in 1919, Sir George Newman became Britain's first Chief Medical Officer. Amongst the four major health concerns he identified in 1919 was "the necessity to secure the health and welfare of childbearing women and infants". In his first annual report he identified "a serious amount of preventable sickness and avoidable disablement". 59 From his position of power and authority he was able to implement, in large part, the recommendations he made in Infant mortality: a social problem.

Newman must be regarded as a notable promoter of child health. A Abt and F $\mathbf{H}$ Garrison in their History of pediatrics linked the emergence of pediatrics as a medical specialty to concern about population problems in children. ${ }^{60}$ Looked at in this light, Newman must be seen as an important and perhaps unrecognized pioneer of paediatrics if this is defined not as a narrow discipline entirely confined to the sick child, but more broadly as concerning the welfare of all children both sick and well. With this in mind, the Dictionary of national biography was right to say of Newman, "no man of this generation did more in this country for public health, medical education and the child". 61

\footnotetext{
53 Alisa Klaus, Every child a lion: the origins of maternal and infant health policy in the United States and France 1890-1920, Ithaca, Cornell University Press, 1993. This book describes the international movement to prevent infant mortality in the early twentieth century focusing on two countries, United States and France, p. 49.

54 Jane Lewis, op. cit., note 46 above, pp. $317-47$

55 C Dyhouse, 'Working-class mothers and infant mortality in England, 1895-1914', in C Webster (ed.), Biology, medicine and society, 1840-1940, Cambridge University Press, 1981, pp. 73-98.

$56 \mathrm{H}$ Marland, 'A pioneer in infant welfare: the Huddersfield scheme 1902-1920', Soc. Hist. Med.,
}

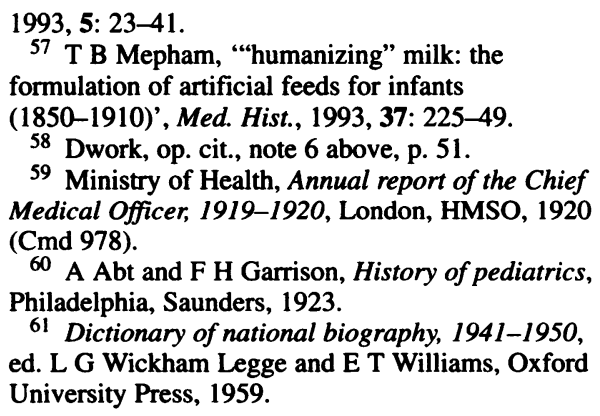

60 A Abt and F H Garrison, History of pediatrics, Philadelphia, Saunders, 1923.

61 Dictionary of national biography, 1941-1950, ed. L G Wickham Legge and E T Williams, Oxford University Press, 1959. 